DOI 10.1515/linpo-2017-0010

\title{
The refinitivization of the infinitive in Finnish
}

\author{
Robert Bielecki \\ Institute of Linguistics, Adam Mickiewicz University in Poznań \\ robertbi@amu.edu.pl
}

\begin{abstract}
Robert Bielecki. The refinitivization of the infinitive in Finnish. The Poznan Society for the Advancement of the Arts and Sciences, PL ISSN 0079-4740, pp. 23-39

An attempt is made to arrange chronologically the particular stages of the diachronic process of the refinitivization of the infinitive based on their synchronic reflections observable in the contemporary Finnish language. The paper begins with an overview of the morphological and syntagmatic properties of various Finnish infinitive types, and a presentation of the adopted taxonomic approach as opposed to the transformational one. The main part contains a discussion on the details and the substantiation of the particular proposed chronological arrangement of the stages of the process of refinitivization of the infinitive in Finnish. A total of six stages of this process are distinguished, as a consequence of which the connection between the infinitive and finite verb tightens to such an extent that the finite verb metamorphoses into an auxiliary verb, whereas the infinitive metamorphoses into the only carrier of lexical meaning in a new compound verb form.
\end{abstract}

Keywords: Finnish verb, finite verb, infinite verb, infinitive, verbal noun, grammaticalization

\section{Introduction}

Verb forms are generally divided into two classes: finite and infinite. Finite verb forms are capable of building, with the appropriate nominal form, a (minimal) sentence. Infinite verb forms lack this potential. The infinitive is one of the subclasses of infinite verb, besides the participle, gerund, etc. The lack of the potential for building a sentence in the case of the infinitive is usually derived from the fact that it lacks the formal exponents of the appropriate meanings characteristic for finite verb forms, particularly person, number, (absolute) tense and mood. The great Danish linguist Otto Jespersen challenged this simplistic approach to the infinitive. In his view, in an English sentence of the type:

(1) I like $\{$ boys to be quiet $\}$. 
it is not the word boys which fulfills the function of the direct object of the transitive verb TO LIKE, but the whole infinitival phrase boys to be quiet. Since the phrase boys to be quiet contains "two ideas which must necessarily remain separate", it resembles in many respects a sentence. Jespersen counts both the sentence Boys are quiet and the infinitival phrase boys to be quiet among the syntactic class of so-called nexuses, as opposed to junctions of the type quiet boys. Recapitulating his considerations of the infinitive, Jespersen emphasizes that it has approached the finite verb morphologically and syntactically, though to varying degrees in different languages (Jespersen 1965: 108-144; cf. also Bogusławski \& Drzazgowska 2016: 247-249).

Further research on the infinitive has furnished a vast empirical body of material confirming that as a result of ongoing grammaticalization processes the syntagm consisting of a finite verb and infinitive displays a cross-linguistic tendency to metamorphose via a compound predicate into a new simple finite verb form. The formation of such a verb form presupposes the following changes:

(i) the old finite verb successively loses its lexical meaning in the process called auxiliarization, whereas

(ii) the infinitive metamorphoses into the only carrier of lexical meaning, the actual lexical root of the new finite verb form (Heine 1993: 27-87).

To illustrate this, let us compare the following Latin example (2) and its successor in modern Spanish (3) (cf. Menéndez Pidal 1987: 322-324):

$\begin{array}{ll}\text { (2) Cantalre habelo. } & >\quad \text { (3) } \begin{array}{l}\text { Cantar/é. } \\ \text { sing-FUTUR I SG } \\ \text { sing-INF have-I SG } \\ \text { 'I have to sing.' }\end{array} \quad \text { 'I will sing.' }\end{array}$

Both the syntactically exceptional (i.e. nexoidal/non-junctional) character of certain types of infinitival phrases and the tendency of the infinitive to merge with the finite verb into a new simple finite verb form seem to be facets of one superior phenomenon which could be named refinitivization of the infinitive. It is obvious that the refinitivization of the infinitive is a diachronic process. The language changes which take place within a diachronic process hardly ever spread in such a way as to erase the previous changes completely. Because of this, the structure of natural languages seems to be rather a result of the successive piling up of the effects of changes with different ranges (cf. Lehtinen \& Laitinen 1997: 11-12). In the present work, by means of morphosyntactic-semantic analysis of different manifestations of the infinitive in contemporary Finnish, an attempt will be made to arrange the synchronic reflections of the respective stages of the refinitivization of the infinitive according to the chronological order of their appearance. 


\section{The system of Finnish infinitives - general information}

In the contemporary Finnish language there are distinguished up to five infinitives. They are traditionally labeled with ordinal numbers: I, II, III, IV and V (cf. Setälä 1926: 105-124; Kettunen \& Vaula 1960: 98-102; Siro 1964: 88-89; Dubrovina 1972: 5; Hakulinen L. 1979: 254-256; Hakulinen A. et al. 2004: 489-490). Each Finnish infinitive has its own characteristic markers:

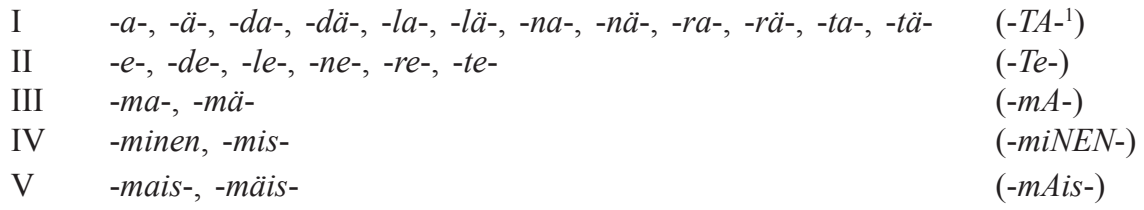

It is well known that, historically, infinitives in Indo-European languages are petrified case forms of old verbal substantives (Brugman 1916: 888-906). The same holds even more transparently for Finno-Ugric languages (Ravila 1945; Uotila 1946; Rätsep 1955; Stipa 1960: 60-62, Saukkonen 1965: 5; Korhonen 1981: 289; Kiuru 1989; Bartens 1999: 144-152; 2000: 228-232). In Finnish, in spite of the fact that the case paradigm of each infinitive has undergone lesser or greater defectivization, the use of many particular infinitival forms still follows strictly the case rectional patterns otherwise valid for nouns. Let us compare:

\section{(4) Minä lähden Suome/en. \\ Finland-ILLAT}

'I am going to Finland.'

(5) Minä lähden $\begin{array}{ccc}\text { Suome/en } & \text { \{opiskele/ma/an suomea }\} . \\ & \text { Finland-ILLAT learn-III INF-ILLAT }\end{array}$
'I am going to Finland \{to learn Finnish\}.'

One of the specific features of Finnish infinitives is that many of their forms are furnishable with markers of an affixal nature carrying meanings characteristic for Finnish finite verbs, such as person, voice and number (tense distinctions are less clear). The following table presents the morphological structure of the five Finnish infinitives, including the infinitive markers as well as the non-zero affixal markers of voice, number (plural - only in the case of the $\mathrm{V}$ infinitive), case and person:

${ }^{1}$ The abstract overall form of all allomorphs of each infinitive is given in parentheses. Capitals denote a possible consonantal/vocal alternation. 


\begin{tabular}{|c|c|c|c|c|c|}
\hline Case & I INF & II INF & III INF & IV INF & V INF \\
\hline $\begin{array}{l}\text { nominative } \\
\text { genitive } \\
\text { partitive } \\
\text { accusative } \\
\text { illative } \\
\text { inessive } \\
\text { elative } \\
\text { allative } \\
\text { adessive } \\
\text { ablative } \\
\text { translative } \\
\text { essive } \\
\text { abessive } \\
\text { instructive } \\
\text { comitative } \\
\text { lative }\end{array}$ & $\begin{array}{l}-T A-k s e-e n^{3} \\
-T A-^{k}\end{array}$ & $\begin{array}{l}-T e-S S A(-A n) \\
-\boldsymbol{T} \boldsymbol{A}^{2}-\boldsymbol{e}-\mathbf{S S} \boldsymbol{A} \\
-\mathrm{Te}-n\left(^{*}-\mathrm{Ni}\right)\end{array}$ & $\begin{array}{l}\text {-mA-An } \\
-m A-s s A \\
\text {-mA-stA } \\
\text {-mA-llA } \\
\\
-m A-t t A(*-A n) \\
-m A-n(*-N i) \\
-\boldsymbol{T A}-\boldsymbol{m} \boldsymbol{A}-\boldsymbol{n}\end{array}$ & $\begin{array}{l}\text {-minen } \\
\text {-mis-tA }\end{array}$ & -mais-i-llA-An \\
\hline
\end{tabular}

As far as the syntagmatic use of the Finnish infinitives is concerned, the first feature that deserves attention is the extreme differences in the connectivity of their particular forms with finite verbs, conditioned by the (lexical) meaning of the latter.

At one of these extremes lie infinitive forms whose connectivity with finite verbs is not subject to limitations. At the opposite extreme are infinitive forms whose connectivity with finite verbs is strictly limited. Because of the high degree of auxiliarization of the finite verbs which can be bound with these infinitive forms, it seems to be hardly possible to ascribe them lexical meaning. There are in fact only three such auxiliary verbs:

\begin{tabular}{|c|c|c|c|}
\hline (i) & $O L L A$ & OLLA -mAis-i-llA-An & 'to be about to (do something)', \\
\hline (ii) & $K \ddot{A} Y D \ddot{A}$ & 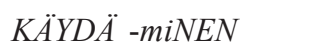 & 'to have to (do something)', \\
\hline iii) & РIT̈̈̈̈ & $\begin{array}{l}\text { РIT̈̈̈̈ }-m A-n \\
P I T \ddot{A} \ddot{A}-T A-m A-n\end{array}$ & $\begin{array}{l}\text { 'to have to (do something)', } \\
\text { 'to have to be (done)'. }\end{array}$ \\
\hline
\end{tabular}

2 The affixal voice markers (-TA-) appear only in case of 1) the inessive of the II infinitive and 2) the instructive of the III infinitive (bolded in the table). The forms of the I infinitive furnished with a non-zero voice marker are considered nowadays as obsolete or dialectal (Penttilä 1963: 491).

${ }^{3}$ The affixal person markers (-en, - An, -Ni) appear only in case of 1) the translative of the I infinitive, 2) the inessive of the II (active) infinitive, and 3) the adessive of the V infinitive. The forms of 1) the instructive of the II infinitive, 2) the abessive of the III infinitive and 3) the instructive of the (active) III infinitive furnished with person markers are considered as rudimentary (marked by an asterisk). 
The remaining infinitive forms can be characterized as lying in the space between these two clear-cut extremes. Let us consider this tripartite classification in more detail:

(i) No limitations:

(a) the translative of the I infinitive (-TA-kse-en),

(b) the inessive of the II infinitive (-Te-ssA(-An), -TA-e-ssA),

(c) the instructive of the II infinitive $(-T e-n)$,

(d) the adessive of the III infinitive $(-m A-l l A)$,

(e) the abessive of the III infinitive $(-m A-t t A)$,

(ii) Moderate limitations:

(a) the lative of the I infinitive $\left(-T A-^{k}\right)$,

(b) the illative of the III infinitive $(-m A-A n)$,

(c) the inessive of the III infinitive $(-m A-s S A)$,

(d) the elative of the III infinitive $(-m A-s t A)$,

(iii) Strict limitations:

(a) the instructive of the III infinitive ( $-m A-n,-T A-m A-n)$,

(b) the nominative of the IV infinitive (-minen),

(c) the partitive of the IV infinitive (-mis-TA),

(d) the adessive of the $\mathrm{V}$ infinitive (-mAis-i-llA-An).

In the $1^{\text {st }}$ and $2^{\text {nd }}$ group there can be distinguished special uses of the relevant infinitives that are characteristic for the $3^{\text {rd }}$ group, but not vice versa. Let us mention some less disputable examples: (1a) the translative of the I infinitive as in: Ovi ei ota avautuakseen 'The door does not let itself be open' (Ikola 1978: 61-62), Tauti menee, jos on mennäkseen 'The disease goes away if it is to go away' (ibid. 65-66), (1e) the abessive of the III infinitive as in: Ole itkemättä 'Don't be crying', Talo on rakentamatta 'The house is not built' (cf. Dubrovina 1972: 198-199), (2a) the lative of the I infinitive as in: Huomenna tulee vastata 'Tomorrow will come the moment to answer' (ibid. 59-60), (2c) the inessive of the III infinitive as in: Hän on lukemassa 'He is reading' (ibid. 170).

\section{The transformational vs. taxonomic approach}

Infinitives can be conceived of as functional equivalents of finite verb forms in more complex structures. For example, the sentence:

(5) Minä lähden Suomeen opiskelemaan suomea.

'I am going to Finland to learn Finnish.'

communicates in relevant respects the same as is communicated by the sequence (a text consisting) of the sentences:

(4) Minä lähden Suomeen. ja

'I am going to Finland.' 'and'
(6) Minä opiskelen suomea Suomessa.

'I will learn Finnish in Finland.' 
An adherent of the transformational approach (cf. Chomsky 1970; Ambrazas 1979) would claim that the sentence Minä lähden Suomeen opiskelemaan suomea comes into being as a result of the merger of the sentences Minä lähden Suomeen and Minä opiskelen suomea Suomessa. The sentence Minä lähden Suomeen would be referred to as the 'embedding sentence', and Minä opiskelen suomea Suomessa as the 'embedded sentence'. The embedding sentence preserves the finiteness of the verb, whereas the embedded sentence converts its finite verb into the infinitive. The procedure of embedding also entails the following change: from the embedded sentence there are removed the words which are homoreferential with words already occurring in the embedding sentence:

embedding sentence:

Minä lähden

Suomeen.

embedded sentence:

Minü

opiskelen

Suomessa suomea.

The approach adopted in the present work will be different. First of all it should be noted that all three analyzed sentence types coexist in the present synchronic state of the Finnish language on the same taxonomic level. None of them is more or less abstract than the others in the literal sense (cf. Bolzano 1978; Itkonen 1991: 58). What differentiates the sentence with the infinitive Minä lähden Suomeen opiskelemaan suomea from the sentences Minä lähden Suomeen and Minä opiskelen suomea Suomessa is its higher degree of syntactic complexity, if only for the trivial reason that it contains three verb complements (Suomeen, opiskelemaan and suomea) instead of two (suomea, Suomessa) or one (Suomeen).

Comparing the monopredicative sentences Minä lähden Suomeen and Minä opiskelen suomea Suomessa it can be stated that within a polypredicative sentence of the type Minä lähden Suomeen opiskelemaan suomea the monopredicative sentence Minä lähden Suomeen finds more equivalents, both lexical and grammatical, than the monopredicative sentence Minä opiskelen suomea Suomessa. Let us compare:

\begin{tabular}{|c|c|c|c|c|c|}
\hline \multirow{2}{*}{$\begin{array}{l}\text { polypredicative } \\
\text { sentence } \\
\text { monopredicative } \\
\text { sentence }\end{array}$} & Minä & lähden & Suomeen & \multirow[t]{3}{*}{ opiskelemaan } & \multirow[t]{3}{*}{ suomea. } \\
\hline & Minä & lähden & Suomeen. & & \\
\hline \multirow{4}{*}{$\begin{array}{l}\text { polypredicative } \\
\text { sentence } \\
\text { monopredicative } \\
\text { sentence }\end{array}$} & $\begin{array}{l}\text { lexical and } \\
\text { grammatical } \\
\text { equivalent }\end{array}$ & $\begin{array}{l}\text { lexical and } \\
\text { grammatical } \\
\text { equivalent }\end{array}$ & $\begin{array}{l}\text { lexical and } \\
\text { grammatical } \\
\text { equivalent }\end{array}$ & & \\
\hline & Minä & lähden & Suome/en & opiskele/ma/an & suomea. \\
\hline & Min̈̈ & & Suome/ssa & opiskele/n & sиотеа. \\
\hline & $\begin{array}{l}\text { lexical and } \\
\text { grammatical } \\
\text { equivalent }\end{array}$ & & $\begin{array}{l}\text { lexical } \\
\text { equivalent }\end{array}$ & $\begin{array}{l}\text { lexical } \\
\text { equivalent }\end{array}$ & $\begin{array}{l}\text { lexical and } \\
\text { grammatical } \\
\text { equivalent }\end{array}$ \\
\hline
\end{tabular}


The syntactic structure of the polypredicative sentence Minä lähden Suomeen opiskelemaan suomea may be depicted as follows:

Minä

subject

Suomeen

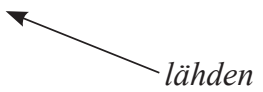

adverbial

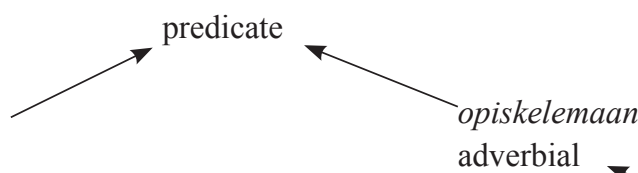

suomea

direct object

Apart from the discussed higher degree of lexical-grammatical equivalency between the sentences Minä lähden Suomeen and Minä lähden Suomeen opiskelemaan suomea than between the sentences Minä opiskelen suomea Suomessa and Minä lähden Suomeen opiskelemaan suomea, it is worth turning attention to the fact that the operation of cancelation applied successively over the sentence Minä lähden Suomeen opiskelemaan suomea, beginning with determinationally the most remote word from the sentence core (subject-predicate) (cf. Bańczerowski 1980: 106), yields at some point only one of the aforementioned monopredicative sentences, i.e. the sentence Minä lähden Suomeen. Let us visualize this by means of the following scheme:

Minä lähden Suomeen opiskelemaan suomea.

Minä lähden Suomeen opiskelemaan stomea.

$\downarrow$

Minä lähden Suomeen opiskelemaan.

$\downarrow$

Minä lähden Suomeen opiskelemaan.

Minä lähden Suomeen opiskelemaan.

Minä lähden Suomeen.

Minä lähden Suomeen.
Minä lähden opiskelemaan.

Minä lähden opisketemaan.

Minä lähden.

Taking into consideration all that has been said, a sentence of the type Minä lähden Suomeen opiskelemaan suomea could be divided into two syntagms: Minä lähden Suomeen and opiskelemaan suomea. Minä lähden Suomeen happens to be a full-fledged sentence, whereas opiskelemaan suomea constitutes a so-called infinitival phrase in which the in- 
finitive as its determinatum absolutum is subordinated syntactically to the predicate of the whole sentence of which it is a part. The arguments of the verb OPISKELLA 'to learn', such as [AGENT] and [LOCUS], are manifested only in the indirect syntactic environment of the infinitive opiskelemaan. This environment happens to be the direct syntactic environment of the finite verb. The formal manifestation of the arguments of the verb which in both types of sentences (i.e. monopredicative and polypredicative) occurs in its finite form does not change according to the mono- or polypredicativity of the sentence. On the other hand, the formal manifestation of the arguments of the verb which in these sentence types occurs once in its finite and once in its infinite form varies according to the mono- or polypredicativity of the sentence.

\section{The mixed verbal-substantival nature of the infinitive}

The great Polish linguist Jerzy Kuryłowicz argued that in opposition to the syntactic group (complex) being externally represented syntactically by its determinatum absolutum, the sentence is externally represented syntactically by a determinans, i.e. its predicate (occurring in a finite verb form). This property of the sentence emerges for example in the phenomenon called consecutio temporum. The formal tense change of the predicate of the subordinate sentence is consequent upon the formal tense change of the predicate of the superordinate sentence, e.g. He says that he will write $\rightarrow$ He said that he would write ([says] : will $\rightarrow$ [said $]:$ would) (Kuryłowicz 1987: 191-198).

From a certain point of view a Finnish infinitival phrase of the type opiskelemaan suomea is a syntactic group. It is represented outside by its determinatum absolutum (i.e. opiskelemaan), which can be corroborated by changing appropriately the exterior syntactic environment. In connection with the verb TULLA 'to come' the III infinitive would acquire the elative case form (with marker $-s t A$ ) governed by this verb:

Minä tulen $\begin{aligned} & \text { Suome/sta } \\ & \text { Finland-ELAT }\end{aligned}$
learn-III INF-ELAT

The change of the illative form (opiskelemaan) to the elative (opiskelemasta) is linked to the substantival character of the infinitive and the rectional character of its relation to the governing verb (cf. the parallel change of the noun Suomeen into Suomesta). However, the change of the finite verb (opiskelen) into the infinitive (opiskelemaan) cannot be substantiated in this way. It would be highly inadequate to maintain that the sound string -ma- appears after the verb stem opiskele- as a kind of nonfunctional ornament. It is obvious that this sound string (called the marker of the III infinitive) is a functional segment of the Finnish language and its appearance is evoked under specific morphosyntactic-semantic conditions. These conditions resemble the conditions necessary to demonstrate the syntactic difference between a group and sentence. Opiskelen (i.e. a determinans in the sentence Minä opiskelen suomea Suomessa) changes into opiskelemaan when incorporated into a more complex structure in which it becomes a direct syntactic deter- 
minans of some other determinans (lähden). Analogously to the change of will into would evoked by the change of [says] into [said], the change of opiskelen into opiskelemaan is evoked by the change of [lähden $j_{-} a_{-}$] into [lähden _ ].

That being so, the distinguishing of phenomena connected with the verbal nature of the infinitive, as manifesting a mechanism of its functioning which seems to be more hidden, from phenomena connected with its substantival nature is a necessary condition for the analysis of the refinitivization of the infinitive.

\section{The connectivity of verbal substantives and infinitives with finite verbs}

It is characteristic for verbal substantives that they are connectable with all finite verbs irrespective of the lexical meaning of the latter. This phenomenon seems at first glance to result from the non-defectiveness of their case paradigm. Verbal substantives are capable of fulfilling the function of all finite verb complements (both obligatory - cf. sentences (8) and (9) - and facultative - cf. sentence (10)), by which token they manifest a higher degree of substantivity than the infinitives. Let us consider some examples:

(8) Jaarittele/minen/Ø ärsyttää minua.

[AGENT] [PATIENT]

witter-SUBST-NOM

'Wittering annoys me.'

(9) Minä en enää siedä tätä jaarittele/mis/ta.

[AGENT] [PATIENT]

witter-SUBST-PART

'I won't stand this wittering anymore.'

(10)

\begin{tabular}{|c|c|c|c|}
\hline Suomen kielen & $\begin{array}{l}\text { opiskele/mise/ksi } \\
\text { [GOAL] }\end{array}$ & minä tarvitsen & $\begin{array}{l}\text { hyvän sanakirjan } \\
\text { [PATIENT] }\end{array}$ \\
\hline
\end{tabular}

learn-SUBST-TRANSL

'In order to learn Finnish I need a good dictionary.'

Nevertheless, as was shown in section 2, in Finnish some forms of the infinitive are also connectable with all finite verbs in the same way. For example:

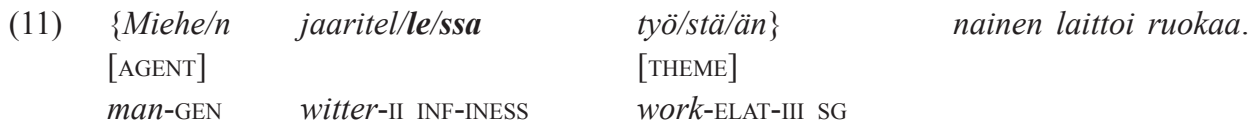

' $\{$ While the husband was wittering about his work $\}$, the wife was preparing food.'

(12)
Mies
[AGENT $]$

$$
\begin{array}{ll}
\text { \{jaaritel/la/kse/en } & \text { työ/stä/än }\} . \\
& {[\text { THEME] }} \\
\text { witter-I INF-TRANSL-III SG } & \text { work-ELAT-III SG }
\end{array}
$$

'The husband came into the kitchen \{in order to witter about his work\}.' 


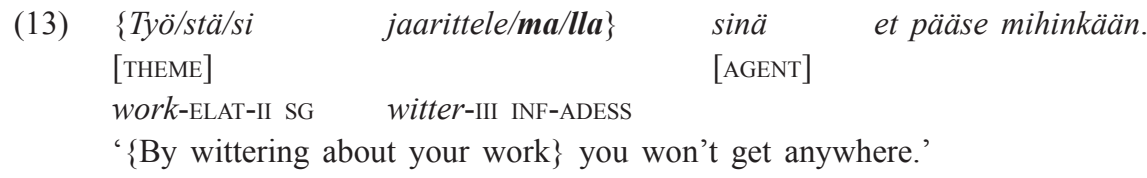

The defectiveness of the case paradigm of the infinitive does not seem to translate directly into the narrowing of the range of finite verbs connectable with it - a phenomenon which demonstrates the more verbal character of the infinitive in comparison with verbal substantives. Nor does the necessary condition seem to be the disappearance of such cases of the old verbal substantives metamorphosing into infinitives which in their primary function encode obligatory complements of the finite verb (cf. sentences (8) and (9)). The infinitive forms being the successors of the verbal substantives fulfilling the function of facultative complements of finite verbs of adverbial character (cf. sentences (11)-(13)) continue to lack limitations as regards their connectivity with finite verbs consequent upon the lexical meaning of the latter. As a consequence of this, such infinitives have a more substantival character than the infinitives connectable with a limited class of finite verbs.

This being so, it is possible to distinguish the following initial stages of the refinitivization of the infinitive and fix the relative order of their appearance:

(I) the disappearance of such case forms of the infinitive which in their primary function encode the obligatory complements of finite verbs,

(II) the disappearance of such case forms of the infinitive which encode the facultative complements of finite verbs of adverbial character.

\section{Establishment of common predicate-argument frames}

It is a characteristic property of phrases containing verbal substantives that they sustain no lexical loss in comparison with their sentential equivalents. Let us compare the following sentences:

(14) Sinä jatkuvasti jaarittelet vain sinun työstäsi.

'You are wittering constantly only about your work.'

(15) Olen tottunut siihen.

'I got used to it.'

(16) Olen tottunut \{sinun jatkuvaan jaarittelemiseesi vain sinun työstäsi\}.

'I got used to \{your constant wittering only about your work\}.'

The full lexical correspondence between the sentence Sinä jatkuvasti jaarittelet vain sinun työstäsi and the phrase containing a verbal substantive sinun jatkuvaan jaarittelemiseesi vain sinun työstäsi is confirmed by the following list of words: 


\begin{tabular}{|c|c|c|c|c|}
\hline $\sin \ddot{a} / \varnothing$ & 'you' & $\leftrightarrow$ & $\operatorname{sinu} / n(-s i)$ & 'your', \\
\hline jatkuva/sti & 'constantly' & $\leftrightarrow$ & jatkuva/an & 'to constant', \\
\hline jaarittele/t & '(you) witter' & $\leftrightarrow$ & jaarittele/mise/e/si & 'to your wittering', \\
\hline ain & 'only' & $\leftrightarrow$ & vain & 'only', \\
\hline$i n u / n(-s i)$ & 'your' & $\leftrightarrow$ & $\operatorname{sinu} / n(-s i)$ & 'your', \\
\hline$\ddot{\boldsymbol{o}} /$ stc & 'about your work' & $\leftrightarrow$ & työ/stä/si & 'about your work'. \\
\hline
\end{tabular}

The occurrence of sentences of the type Olen tottunut jatkuvaan jaarittelemiseen vain työstä 'I got used to constant wittering only about work', with no lexical exponent of the [AGENT] of wittering, does not undermine what has been said above about phrases containing verbal substantives. The verbal substantive jaaritteleminen 'wittering' opens a potential syntactic slot for it.

In contrast to phrases containing verbal substantives, infinitival phrases reveal some lexical loss in comparison with their sentential equivalents, for example:

Sinä tulet tähän.

'You come here.'

(14) Sinä jatkuvasti jaarittelet vain sinun työstäsi.

'You are wittering constantly only about your work.'

(18) Sinä tulet tähän \{jatkuvasti jaarittelemaan vain sinun työstäsi\}.

'You come here \{to witter constantly only about your work\}.'

The infinitival phrase jatkuvasti jaarittelemaan vain sinun työstäsi is found to be only a partial lexical equivalent of the sentence Sinä jatkuvasti jaarittelet vain sinun työstäsi, since it does not contain the lexical exponent of the [AGENT] of wittering.

The absence or presence of the discussed lexical loss within the analyzed phrase types seems to be a reflection of different degrees of establishment of common predicate-argument frames between the verbal substantive/infinitive and the finite verb.

In the sentence containing a verbal substantive the intensity of the establishment of common predicate-argument frames is potentially zero, because both the verbal substantive and finite verb retain the lexical exponents of their arguments in their direct syntactic environment:

[AGENT]-JAARITELLA-[THEME]

[AGENT]-TOTTUA-[GOAL] cf. sinun jaarittelemisesi työstä

'your wittering about the work'

cf. Minä olen tottunut jaarittelemiseesi

'I got used to your wittering'

Again, the occurrence of sentences of the type Minä en pidä jaarittelemisesta 'I do not like to witter', containing the verbal substantive, with the common lexical exponent of the [AGENT] of both liking and wittering in the direct syntactic environment of the finite verb, does not undermine what has been said about phrases containing verbal substantives. The verbal substantive jaaritteleminen 'wittering' opens a potential syntactic slot for a lexically different [AGENT] of wittering: Minä en pidä sinun jaarittelemisestasi 'I do not like your wittering'. 
In turn, in the sentence with the infinitival phrase the degree of establishment of common predicate-argument frames with the finite verb is higher (non-zero), because the infinitive does not retain the lexical exponent of one of its arguments in its direct syntactic environment. This argument becomes lexicalized in the direct syntactic environment of the finite verb:

[AGENT]-TULLA

[AGENT]-JAARITELLA-[THEME] cf. Sinä tulet

'You come'

cf. Ø jaarittelemaan työstä

'to witter about the work'

In the examples analyzed so far, the establishment of common predicate-argument frames between the infinitive and finite verb proceeded in such a way that one of the arguments of the infinitive became lexicalized in the direct syntactic environment of the finite verb. The historical shift in the opposite direction, i.e. when one of the arguments of the finite verb becomes lexicalized in the direct syntactic environment of the infinitive, seems to be much more significant from the point of view of the phenomenon being analyzed here. Let us take a closer look at the following example:

$\begin{array}{llll}\text { Nainen ei antanut } & \{\text { miehe/n } & \text { jaaritel/la }^{k} & \text { työ/stä/än }\} . \\ & {[\text { AGENT }]} & & {[\mathrm{THEME}]} \\ & \text { man-GEN } & \text { witter-I INF-LAT } & \text { work-ELAT-III SG }\end{array}$

'The wife did not let \{the husband witter about his work\}.'

According to Ikola (1954: 215-219; cf. also Ikola 1959: 51-57) this type of infinitival phrase came into being as a result of the reinterpretation of sentences of the type:

$\begin{array}{llll}\dagger \text { Anna/n } & \text { vede/n } & \left\{\text { valu/a }{ }^{k}\right. & \text { ammee } / \text { seen }\} . \\ \text { give-I SG } & \text { water-ACC } & \text { flow-I INF-LAT } & \text { bathtub-ILLAT }\end{array}$

The sentence $\dagger$ Annan veden \{valua ammeeseen $\}$ formerly communicated first of all that I give the water in the literal sense. The fact that as a consequence of the action of giving the water flows into the bathtub was treated as a matter of secondary importance. This was expressed by means of a facultative adverbial. ${ }^{4}$ The aforementioned reinterpretation consisted in a shift of the word veden 'the water' from the direct syntactic environment of the finite verb (Annan 'I give') to the direct syntactic environment of the infinitive (valua 'to flow'):

$\dagger$ Annan veden $\{$ valua ammeeseen $\} . \quad>$ Annan $\{$ veden valua ammeeseen $\}$.

As a result of this shift veden changed its casal affiliation from accusative (in connection with the finite active transitive verb Annan 'I give') to genitive (in connection

${ }^{4}$ In the contemporary Finnish language the analogous meaning would be rendered by the sentence Laitoin veden \{valumaan ammeeseen 'I loaded the water \{to flow to the bathtub\}.' 
with the infinitive), which in the singular number happen to be largely syncretic (cf. Bielecki 2015: 103-112). After the finite verb Annan had been deprived of any substantival complement, it was determined syntactically directly only by some other verb ( $V A$ $L U A$ 'to flow'). As a result of such a junction of two verbs the meaning of the finite verb became more abstract, changing from 'to give' to 'to let/allow'. The finite verb Annan acquires different meanings depending on whether or not it is determined syntactically only by the infinitive. In the case of verbal substantives, analogous dependencies do not occur. The substitution of jaaritteleminen 'wittering' by, for example, the noun meteli 'noise' in the sentence Olen tottunut jaarittelemiseen 'I got used to the wittering' does not evoke a change of the meaning of the finite verb TOTTUA (Olen tottunut meteliin 'I got used to the noise'). The described moment of occurrence of the change of meaning of the finite verb in connection with the infinitive can be regarded as the real starting point of the auxiliarization of the finite verb and a key turning point in the refinitivization of the infinitive.

Taking into account all that has been said, it is possible to distinguish the next two stages of the refinitivization of the infinitive:

(III) the establishment of common predicate-argument frames between the infinitive and finite verb wherein one argument of the infinitive becomes lexicalized in the direct syntactic environment of the finite verb,

(IV) the establishment of common predicate-argument frames between the infinitive and finite verb wherein one argument of the finite verb becomes lexicalized in the direct syntactic environment of the infinitive, and thus the infinitive becomes potentially the only direct syntactic determinans of the finite verb.

\section{The de-eventivization of the finite verb}

As has been signaled in the Introduction, the auxiliarization of the finite verb in connection with the infinitive leads to loss of the lexical meaning of the finite verb. For example, in a sentence of the type:

$$
\begin{array}{ll}
\text { Hän oli } & \text { laula/ma/ssa. } \\
& \text { sing-III INF-INESS }
\end{array}
$$

'He was singing.'

the verb OLLA no longer conveys the meaning 'to be at a certain place/to exist'. That being so, it is deprived of its real eventive references. At first glance, the auxiliary verb $S A A D A$ 'can' seems to behave in an analogous manner. A sentence of the type:

$$
\begin{aligned}
H a ̈ n & \text { sai } \quad l a u l a / \boldsymbol{a} /{ }^{k} . \\
& \text { sing-I INF-LAT }
\end{aligned}
$$

'He could sing.' 
communicates in this precise form only one event, namely the event of singing, which is presented in the light of the deontic modality expressed by the verb $S A A D A$. Nevertheless a compound predicate of the type sai laulaa 'could sing' seems to function in a latent manner differently from a compound predicate of the type oli laulamassa 'was singing'. The propositional content of the sentence Hän sai laulaa tätä laulua 'He could sing this song' does not differ from the propositional content of Hän oli laulamassa tätä laulua 'He was singing this song'. Both sentences express the same arrangement of things: $H E-S I N G-T H I S-S O N G$. However let us take a closer look at the following sentences with the adverb innokkaasti 'eagerly':

(23) Hän oli laulamassa tätä laulua innokkaasti.

'He was singing this song eagerly.'

(24) Hän sai laulaa tätä laulua innokkaasti.

'He could sing this song eagerly.'

The sentence Hän oli laulamassa tätä laulua innokkaasti implies that the eagerness to sing is an individual feature of the singer. The sentence Hän oli innokas laulamaan tätä laulua 'He was eager to sing this song', perceived as its paraphrase, seems to corroborate this. In turn, the sentence Hän sai laulaa tätä laulua innokkaasti does not contain such an implication. It communicates that eagerness was a property of the manner of singing allowed by somebody else. The singer himself did not necessarily have to be eager to sing.

This discrepancy may result from the fact that in spite of the auxiliarization of the verb $S A A D A$ it still retains some traces of its eventiveness. In a sentence of the type:

$\begin{array}{llll}\text { Hän } & \text { sai } & \text { luva/n } & \text { isä/ltä. } \\ \text { [AGENT-BENEFICIENT] } & & \text { [PATIENT] } & \text { [DONOR-AGENT] } \\ \text { he-NOM } & & \text { permission-ACC } & \text { father-ABL }\end{array}$

'He received permission from his father.'

where $S A A D A$ still occurs as an autosemantic verb, the [AGENT] of receiving is at the same time the [BENEFICIENT] of the giving of permission (Ḧ̈N 'he'). De-eventivization of the verb $S A A D A$ in a sentence of the type Hän sai laulaa tätä laulua innokkaasti manifests itself by the fact that both the [DONOR] and simultaneously the [AGENT] of giving (ISÄ 'father') and the [PATIENT] of giving (LUPA 'permission') are not lexicalizable. Nevertheless the lexicalizable [AGENT] of singing seems to have retained its role as a [BENEFICIENT] of the giving of permission, which is not the case with a predicate of the type oli laulamassa 'he was singing'. The different implications concerning the range of reference of the adverb innokkaasti 'eagerly' resulting from the sentences Hän oli laulamassa tätä laulua innokkaasti and Hän sai laulaa tätä laulua innokkaasti are seemingly a consequence of different diathetic structures underlying these sentences (cf. also Chojak 2009: 131). Hän in Hän oli laulamassa tätä laulua innokkaasti encodes only the [AGENT] of singing, whereas Hän in Hän sai laulaa tätä laulua innokkaasti encodes both the [AGENT] 
of singing and the [BENEFICIENT] of the giving by a non-lexicalizable [DONOR] of a non-lexicalizable permission to sing.

The two last stages identified according to the presented line of reasoning can be described as follows:

(V) the partial de-eventivization of the finite verb manifesting through its latent diathetic functioning its paradigmatic connection to a fully eventive autosemantic verb,

(VI) the total de-eventivization of the finite verb.

\section{Summary and conclusions}

Observations made about many natural languages confirm that the structure of these languages is a result of the successive piling up of the effects of diachronic changes with different ranges. The aim of this paper was to arrange the synchronic reflections of the respective stages of the phenomenon of the refinitivization of Finnish infinitives according to the chronological order of their appearance, based on material excerpted from the contemporary Finnish language.

In the sections devoted to more general information there was first provided an overview of the morphological and syntagmatic properties of Finnish infinitives. A description was also given of the adopted taxonomic approach, standing in a kind of opposition to the transformational approach. The distinguishing phenomena resulting from the substantival and verbal nature of the infinitive was evaluated as significant for the analysis being undertaken.

The process of the refinitivization of Finnish infinitives was observed from the point of view of three phenomena:

(i) the connectivity of infinitives with finite verbs conditioned by the (lexical) meaning of the latter,

(ii) the establishment of common predicate-argument frames between the infinitive and finite verb, and

(iii) the de-eventivization of the finite verb.

A total of six stages of the process were distinguished:

(i) the disappearance of such case forms of the infinitive which in their primary function encode the obligatory complements of finite verbs,

(ii) the disappearance of such case forms of the infinitive which encode the facultative complements of finite verbs of adverbial character,

(iii) the establishment of common predicate-argument frames between the infinitive and finite verb wherein one argument of the infinitive becomes lexicalized in the direct syntactic environment of the finite verb, 
(iv) the establishment of common predicate-argument frames between the infinitive and finite verb wherein one argument of the finite verb becomes lexicalized in the direct syntactic environment of the infinitive, and thus the infinitive becomes potentially the only direct syntactic determinans of the finite verb,

(v) the partial de-eventivization of the finite verb, manifesting through its latent diathetic functioning its paradigmatic connection to a fully eventive autosemantic verb, and

(vi) the total de-eventivization of the finite verb.

As a result of this process the substantival nature of the infinitive successively gives way to its verbal nature. The connection between the infinitive and finite verb is tightened. In the final stage of the process the finite verb loses its autosemanticity by metamorphosing into an auxiliary verb. In turn, the infinitive metamorphoses into the only carrier of lexical meaning in a new compound verb form.

Further potential stages in which the infinitive loses its linear separability from the finite verb, while its affix is deprived of the function of signaling syntagmatic relations, seem to be irrelevant to the analyzed phenomenon, because in such a case we are no longer dealing with an infinitive at all. The infinitive is after all considered to be a word, independently of its more or less free syntactic status.

I hope that this relatively short paper may serve as a contribution to a more profound, detailed and subtle investigation into such a complicated and - as it seems - still not satisfactorily resolved matter as the morphosyntax and semantics of the infinitive, both language-specific and general.

\section{Abbreviations and symbols}

$\begin{array}{llll}\text { Ø } & \text { (morphological) zero } & \text { ILLAT } & \text { illative (case) } \\ \text { [AGENT] } & \text { verb arguments } & \text { INESS } & \text { inessive (case) } \\ \{\} & \text { syntactic group } & \text { INF } & \text { infinitive } \\ > & \text { historical change } & \text { LAT } & \text { lative (case) } \\ \dagger & \text { historical reconstruction } & \text { NOM } & \text { nominative (case) } \\ \text { ABL } & \text { ablative (case) } & \text { OLLA } & \text { a word as an abstract set of actual word(form)s } \\ \text { ACC } & \text { accusative (case) } & \text { PART } & \text { partitive (case) } \\ \text { ADESS } & \text { adessive (case) } & \text { SG } & \text { singular (number) } \\ \text { ELAT } & \text { elative (case) } & \text { SUBST } & \text { substantivizing affix } \\ \text { FUTUR } & \text { future (tense) } & \text { TRANSL } & \text { translative (case) } \\ \text { GEN } & \text { genitive (case) } & & \end{array}$

\section{References}

Ambrazas, Vytautas. 1979. Lietuviu kalbos dalyviu istorine sintaksè. Vilnius: Mokslas.

Bańczerowski, Jerzy. 1980. Systems of Semantics and Syntax. A Determinational Theory of Language. Warszawa, Poznań: PWN.

Bartens, Raija. 1999. Mordvalaiskielten rakenne ja kehitys. Helsinki: Suomalaisen Kirjallisuuden Seura. 
Bartens, Raija. 2000. Permiläisten kielten rakenne ja kehitys. Helsinki: Suomalaisen Kirjallisuuden Seura.

Bielecki Robert. 2015. Finnish Case Grammar. From the Syntactic and Semantic Perspectives. Poznań: Wydawnictwo Naukowe UAM.

Bogusławski, Andrzej \& Drzazgowska, Ewa. 2016. Język w refleksji teoretycznej. Przekroje historyczne. Warszawa: Katedra Lingwistyki Formalnej Uniwersytetu Warszawskiego.

Bolzano, Bernard. 1978. Dr. B. Bolzanos Wissenschaftslehre. Versuch einer ausführlichen und größtentheils neuen Darstellung der Logik mit steter Rücksicht auf deren bisherige Bearbeiter. In Kambartel, Friedrich (ed.), Bernard Bolzanos Grundlegung der Logik. Ausgewählte Paragraphen aus der Wissenschaftslehre, Band I und II, 197-365. Hamburg: Felix Meiner Verlag.

Brugman, Karl. 1916. Vergleichende Laut-, Stammbildungs- und Flexionslehre nebst Lehre vom Gebrauch der Wortformen der indogermanischen Sprachen. Strassburg: Karl J. Trübner.

Chojak, Jolanta. 2009. Zrozumieć jak. Studium składniowo-semantyczne. Warszawa: BEL Studio.

Chomsky, Noam. 1970. Remarks on nominalization. In Jacobs, Roderick \& Rosenbaum, Peter (eds.), Readings in English Transformational Grammar, 184-221. Waltham, Toronto, London: Ginn and Company.

Dubrovina, Zinaida. 1972. Инфинитивы в финском языке. Saint-Petersburg: Издательство Ленинградского университета.

Hakulinen, Auli \& Vilkuna, Maria \& Korhonen, Riitta \& Koivisto, Vesa \& Heinonen, Tarja Riitta \& Alho, Irja. 2004. Iso suomen kielioppi. Helsinki: Suomalaisen Kirjallisuuden Seura.

Hakulinen, Lauri. 1979. Suomen kielen rakenne ja kehitys. Helsinki: Kustannusosakeyhtiö Otava.

Heine, Bernd. 1993. Auxiliaries. Cognitive Forces and Grammaticalization. New York, Oxford: Oxford University Press.

Ikola, Osmo. 1954. Suomen lauseopin ongelmia. Virittäjä 58. 209-245.

Ikola, Osmo. 1959. Eräistä suomen syntaktisista siirtymistä. Sananjalka 1. 39-60.

Ikola, Osmo. 1978. Lauseenvastikeoppia. Nykysuomen lauseenvastikkeiden ja niihin verrattavien rakenteiden selvittelyä. Helsinki: Suomalaisen Kirjallisuuden Seura.

Itkonen, Esa. 1991. Universal History of Linguistics. India, China, Arabia, Europe. Amsterdam, Philadelphia: John Benjamins Publishing Company.

Jespersen, Otto. 1965. The Philosophy of Grammar. New York: The Norton Library.

Kettunen, Lauri \& Vaula, Martti. 1960. Suomen kielioppi. Porvoo, Helsinki: Werner Söderström Osakeyhtiö.

Kiuru Silva. 1989. Kolmannen infinitiivin olosijat ja vanha kirjasuomi. Virittäjä 93. 432-445.

Korhonen, Mikko. 1981. Johdatus lapin kielen historiaan. Helsinki: Suomalaisen Kirjallisuuden Seura.

Kuryłowicz, Jerzy. 1987. Studia językoznawcze. Wybór prac opublikowanych w języku polskim. Warszawa: PWN.

Lehtinen, Tapani \& Laitinen, Lea (eds.). 1997. Kieliopillistuminen. Tapaustutkimuksia suomesta. Helsinki: Helsingin yliopiston suomen kielen laitos.

Menéndez Pidal, Ramón. 1987. Manual de gramática histórica española. Madrid: Espasa-Calpe.

Penttilä, Aarni. 1963. Suomen kielioppi. Porvoo, Helsinki: Werner Söderström Osakeyhtiö.

Ravila, Paavo. 1945. Nomen verbale suomalais-ugrilaisissa kielissä. Virittäjä 49. 148-158.

Rätsep, Huno. 1955. Läänemeresoome keelte $t$-lise infinitiivi päritoluga seoses olevaid probleeme. Emakeele Seltsi aastaraamat I. 152-162.

Saukkonen, Pauli. 1965. Itämerensuomalaisten kielten tulosijainfinitiivirakenteiden historiaa I. Helsinki: Suomalaisen Kirjallisuuden Seura.

Setälä, Eemil Nestor. 1926. Suomen kielen lauseoppi oppikouluja varten. Helsinki: Otava.

Siro, Paavo. 1964. Suomen kielen lauseoppi. Helsinki: Tietosanakirja Oy.

Stipa, Günter. 1960. Funktionen der Nominalformen des Verbs in den Permischen Sprachen. Helsinki: Suomalais-Ugrilainen Seura.

Uotila, Toivo Emil. 1946. Suomen I infinitiivistä. Virittäjä 50. 442-452. 